\title{
To Be Ethical Or Not To Be: An International Code Of Ethics For Leadership
}

Ala' Alahmad, University of the Incarnate Word, USA

\begin{abstract}
To be ethical or not to be that is the question? Leadership is about setting the right example and making a difference in people's lives. You do not have to do great things to make a difference (Ayres, 2004). Honesty, tell the truth no matter what, respect, punctuality, not judgmental, just, humble, and dignity can be international code of ethics every leader should follow. Much has changed in our world in the past several decades including people's beliefs of what is right and wrong. Have their ethics changed as well? This paper introduces an international code of ethics that can guide all different international leadership styles. What is the definition of Ethical Leadership? How can we introduce an international code of ethics for leadership? Finally, leadership is all about example. While an extensive review of literature was not conducted, this researcher was unable to identify an international code of ethics for leadership. Consequently, it is the opinion of this researcher that the following leader characteristics may apply beyond international and cultural boundaries in most instances- honesty, tell the truth no matter what, respect, punctuality, not judgmental, just, humble, and dignity.
\end{abstract}

Keywords: Leadership style, ethics, honesty, truth, respect, punctual, judgmental, just, humble, dignity

\section{INTRODUCTION}

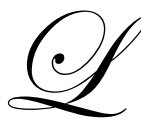
eadership style might differ from one place to another. Leaders might practice their leadership styles based upon the culture from which they grew. Therefore, understanding leadership is a call to understand the cultural context in which it takes place (Nahavandi, 2009). Culture may not be the only factor that affects leadership style. Some research suggested that unique traits shape leaders personalities and behaviors (Carlyle 1907; Galton 1869; James 1880). Others believe values are desirable and worthwhile. One value related to leadership is ethics. Ethics are a person's concept of right and wrong. However, we do not all share the same understanding of right and wrong. There are two general views of ethics: relativist and universalist (Donaldson, 1994). The relativist view of ethics believes what is right or wrong, is situational or dependent upon the culture. In contrast a universalist view of ethics believes all activities should be judged by the same standards, whatever the situation or culture. Individuals can choose what is ethically appropriate for themselves. But do we really have such universalistic ethics?

\section{SIGNIFICANT OF THE PROBLEM}

Unfortunately, one of the main problems that we face in the world today is the lack of ethical leadership. The aim of this paper is to suggest an international code of ethics for leadership. The theme of the suggested international code of ethics is honesty, tell the truth no matter what, respect, be punctual, not judgmental, just, humble, and dignity.

Much has changed in our world in the past several decades including people's beliefs of what is right and wrong. Have their ethics changed as well? This paper introduces an international code of ethics that can guide all different international leadership styles. What is the definition of Ethical Leadership? How can we introduce an international code of ethics for leadership? 


\section{ETHICAL LEADERSHIP}

Humans often try to define their actions behaviors and relationships. These relationships involve not only family, friends, and coworkers but ourselves as well. We try to give relevant meaning to the life we live, by giving meaning to the environment, animals, and even objects. We do this to be fair with aspects of our life and seek acceptance from others. Possibly we desire life to be easier and reasonable. Could it be that we desire things to be more convenient or is it because complicated issues require clarification, as ethical or unethical?

Some suggest that ethical leadership is strongly related to the culture (Donaldson, 1994). Others believe there is no general theory of ethical leadership (Rubenstein, 2003; O'Connor, 2006). But what has been developed in the definition of ethical leadership is interesting. Through their qualitative research (Brown \& Trevino, 2002) were able to give a clear definition of ethical leadership. According to Brown and Trevino (2002) ethical leadership is the demonstration of normatively appropriate conduct through personal actions and interpersonal relationships, and promotion of such conduct among followers through two-way communication, reinforcement, and decision-making processes. However, their qualitative study could be a success if we were looking at their definition as what Donaldson suggested as relativist view of ethics. Global and cross-cultural ethics are still highly complex to define (Nahavandi).

\section{SOLUTIONS AND OUTCOMES}

The United Nations has tried to promote and encourage ethical leadership in the international arena. An example of such attempt was the Peace and Governance Programme of the United Nations that worked under the following three assumptions. 1) Human rights and ethics, far from constituting two separate areas of study, have to be understood as two related and complementary fields, each of them contributing to and projecting - particularly through multilateralism - a sense of international community. 2) Inhabiting the activities in this area is that addressing issues of human rights and ethics is part of a wide conception of human security which is currently emerging - a conception of human security which does not limit itself to traditional security issues, but also encompasses norms and value-judgments. 3) Making human rights and ethics a core aspect of the Peace and Governance Programme is meant to contribute to an inquiry on the making and evolution of the contemporary democratic culture, both within borders and among nations. This Programme area therefore contributes to debate regarding the normative underpinnings of the institutions and values that are used to organize our lives (United Nations University, 2008)

The Peace and Governance Programme completed four projects in the issues of human rights and ethical leadership. The Age of apologies and Ethics in actions were two of these projects. Within the past few years several Western states have acknowledged and apologized for past "wrongs" committed. The United Nation has taken steps to recognize their responsibility in mishandling humanitarian crises and have come to apologize to the victims like Srebrenica and Rwanda. Furthermore, the ethics in actions project aims to examine the challenges of work in the field. This involves both "neutral" practices of humanitarian assistance within local institutional constraints, and the more "politicized" transmission of global human rights norms.

In addition, the United Nation has established an Ethics office. The Ethics Office is established as a new office within the United Nations Secretariat reporting directly to the Secretary-General. The main responsibilities of the Ethics Office are as follows: (United Nation, 2005)

1. Administering the Organization's financial disclosure programme;

2. Undertaking the responsibilities assigned to it under the Organization's policy for the protection of staff against retaliation for reporting misconduct and for cooperating with duly authorized audits or investigations;

3. Providing confidential advice and guidance to staff on ethical issues (e.g., conflict of interest), including administering an ethics helpline;

4. Developing standards, training and education on ethics issues, in coordination with the Office of Human Resources Management and other offices as appropriate, including ensuring annual ethics training for all staff; 
5. Such other functions as the Secretary-General considers appropriate for the Office.

It is interesting to note that the United Nations has an Ethics Office; however, the Ethics Office of the United Nations has not taken any steps to develop a code of ethics for international leaders.

\section{INTERNATIONAL CODE OF ETHICS FOR LEADERS}

To be ethical or not to be that is the question? Leadership is about setting the right example and making a difference in people's lives. You do not have to do great things to make a difference (Ayres, 2004). Honesty, tell the truth no matter what, respect, punctuality, not judgmental, just, humble, and dignity can be international code of ethics every leader should follow.

It is indeed difficult but not impossible to be honest and to tell the truth these days. "To make your children capable of honesty is the beginning of education," (John Ruskin as cited Clemson University, 2007). "Honesty is the best policy. If I lose mine honor, I lose myself," (William Shakespeare as cited by Wisdom Commons, 2008). "If you tell the truth, you don't have to remember everything," (Mark Twain, as cited by MetaFilter, 2009). Telling the truth honors and respects your profession (Adams, 2004). It has been always believed that both honesty and telling the truth complete each other. You cannot be honest to yourself and not to others. Leaders must tell the truth in its full version not half of it. If the truth is told in half that means it is a lie. Some people believe it is really hard to be honest and to say the truth in societies that are full of corruption. But I'm one of those who believe that being honest and always telling the truth no matter what is a must to be able to have a peaceful sleep night.

"Do to people as you would be done by," (Baalbaki, trans. 1986). Most of us (if not all) would love to be respected by others unless we refuse to! But you would ask; how would some people not welling to be respected? It is known that the way you treat people is the way you would love people to treat you. Each one of us must ask him/herself, do I really respect others? Do leaders followers? Do they tolerate some mistakes? Do I leaders smile to others? A lot of (DOIs) must be taken in consideration before start seeking respect from others.

Although punctuality can be part of respecting others, some can see it as an ethical issue. In his book Ciulla (1998) stated, "If ethics are part of life, so too are work, labor, and business." Being punctual -in my opinion- is considered ethical. It is important for leaders to come to work on time, to be at the meeting on time - this will show how much you value others and the institution you work for.

Unfortunately, some leaders judge a book by its cover and rarely can be just with others. Leadership is the art of influencing others. A leader must be just and fair with his followers (Lutz, 1986). It is more important to consider whom our actions might harm, whose feeling we might hurt, what is bad for others, or what obstacles we might create for ourselves, than to judge the bad qualities of others. So before we misunderstand someone, or are ready to debate about something, we should consider whether we have understood correctly what the other person really meant, or whether what we are about to do is what the boss would want you to do. On the other hand, to be just is really a hard thing to do for some leaders. What an awful feeling when we are treated unfairly. One reason maybe in my opinion is that for some leaders when having the power they tend to use it the way they think helps others. Indeed they use the power in a way that helps their interests.

Furthermore, it is hard to be humble, when you are perfect in every way! Very few leaders, of course, actually think they are perfect in every way, but it can still be pretty hard to be humble, especially when you live in a society that encourages competition and individuality. Humble leaders assume they do not know everything and make employees explain to them, doing this makes others (followers and employees) feel valued about themselves (McCarty, 2008). Leaders who recognize they are not perfect create an environment where those around them feel comfortable making mistakes and taking chances (McCarty). Being humble does not mean you cannot feel good about yourself. Think about the things you have and be thankful for having them.

Another ethical issue that leaders do not pay attention to is dignity. Dignity as defined in Wikipedia (2004) as a moral, ethical, and political discussions to signify that a being has an innate right to be respected and ethically treated. So, how many of us still have it? Don't we remember what happened in Baghdad at Al Ghraib prison (by 
some individuals)? Leaders must respect the rights and dignity of all people (Holloway, 2006). It is a must that each person's dignity must be respected, even if the person is a convicted criminal. I believe that people are more important than things; therefore, we must consider their rights of being humans.

\section{SUMMARY}

Ethics are a person's concept of right and wrong (Nahavandi, 2009). However we do not all share the same understanding of right and wrong. Other suggested that there are two general views of ethics: relativist and universalist. Some suggested that ethical leadership is strongly related to the culture (Donaldson, 1994). Others believe there is no general theory of ethical leadership (Rubenstein, 2003; O'Connor, 2006). On the other hand, ethical leadership is the demonstration of normatively appropriate conduct through personal actions and interpersonal relationships, and promotion of such conduct among followers through two-way communication, reinforcement, and decision-making processes (Brown \& Trevino, 2002).

The United Nation efforts to encourage ethical leadership are quiet recognized by establishing Ethics Office and the Peace and Governance Programme. Unfortunately, these efforts were not capable of developing a code of ethics for international leaders.

Finally, leadership is all about example. While an extensive review of literature was not conducted, this researcher was unable to identify an international code of ethics for leadership. Consequently, it is the opinion of this researcher that the following leader characteristics may apply beyond international and cultural boundaries in most instances-honesty, tell the truth no matter what, respect, punctuality, not judgmental, just, humble, and dignity.

\section{AUTHOR INFORMATION}

Ala' H. Alahmad is a PhD student in the Incarnate Word University majoring in organizational Leadership. His research paper focuses on viewpoint of leadership effectiveness. Ala' graduated from the University of the Incarnate Word in the year of 2008 with an M.A in Education with a concentration in TESL and TEFL (Teaching English as Second Language and as a Foreign Language). In the year of 2008 he was awarded for being an Outstanding International Student at the University of the Incarnate Word, 2008. He has earned his B.A degree in English Literature in the year of 2002 from Irbid National University in Jordan.

\section{REFERENCES}

1. Ayres, R. (2004). Leading by example: How we learn about leadership. Retrieved July 13, 2009 from http://www.neiassociates.org/leadbyexample.htm

2. Baalbaki, M. (1986). Al Mawrid: English-Arabic dictionary. Dar Alsalam print.

3. Brown, M \& Trevino, L. (2002). Measures for Leadership Development: Ethical Leadership Scale. Retrieved July 15, 2009, from http://www.uwec.edu/sampsow/Measures/Leadership-ELS.htm

4. Carlyle, T. (1907). Heroes and hero worship. Bosten: Adams.

5. Ciulla, Joanne B. (ed.) (1998) Ethics the Heart of Leadership. Westport, Connecticut: Praeger.

6. Clemson University (2007). Quotes related to the fundamental values of academic integrity. Retrieved July 13, 2009, from http://www.academicintegrity.org/fundamental_values_project/quotes_on honesty.php

7. Donaldson, T. (1994).Global business must mind its morals. New York Times, February 13, F11.

8. $\quad$ Eddie Adams. (2004). Powerful Truth: News Photographer, Retrieved April 18th, 2009, from Academic Search Complete database.

9. Erickson, A. (2006). Ethical Leadership and the Public Trust. Public Manager, 35(1), 62-63. Retrieved April 15th, 2009, from Academic Search Complete database.

10. Galton, R. (1869). Hereditary genius. New York: Appleton.

11. Holloway, J. (2006, January 1). Model Behavior. Principal Leadership, 6(5), 44-48. (ERIC Document Reproduction Service No. EJ767023) Retrieved April 11th, 2009, from ERIC database.

12. James, W. (1880). Great men, great thoughts, and their environment fit. Journal of Management Issues 18:193-212. 
13. Lutz, C. (1986, April 1). Attributes of a Good Leader. Vocational Education Journal, 61(3), 28-30. (ERIC Document Reproduction Service No. EJ348715) Retrieved April 11th, 2009, from ERIC database.

14. MetaFilter (2009). Community weblog. Retrieved July 13, 2009, from http://www.metafilter.com/68852/Commitment-ceremony-or-needing-to-be-committed

15. McCarty, L. (2009). The humble leader. Retrieved April 14, 2009, from http://www.emergingleader.com/article20.shtml

16. Nahavandi, A. (2009) The Art and Science of Leadership. N.J.: Prentice Hall.

17. O'Connor, T. (2006). Ethical leadership and policymaking. Retrieved July 15, 2009, from http://www.apsu.edu/oconnort/3300/3300lect07.htm

18. Rubenstein, H. (2003). Ethical Leadership. Retrieved, July 15, 20092003, from http://www.conservativemonitor.com/opinion03/28.shtml

19. United Nation (2005). Ethics Office - establishment and terms of reference. Retrieved July 16, 2009, from http://www.un.org/reform/ethics/index.shtml

20. United Nation University (2008). Human rights and ethics. Retrieved July 16, 2009, from http://www.unu.edu/pg/rights/

21. Wikipedia (2004).Dignity. Retrieved April 15th, 2009 from http://en.wikipedia.org/wiki/dignity.

22. Wisdom Commons (2008). Exploring, elevating and celebrating our moral core. Retrieved July 14, 2009, from http://www.wisdomcommons.org/wisbits/2202-honesty-quotes-honor-quotes-honesty-is-the-bestpolicy 
NOTES 